\title{
ANALISIS KESIAPSIAGAAN BENCANA PADA SISWA DAN GURU DI SEKOLAH DASAR NEGERI 6 MATARAM
}

\author{
Syahrial Ayub¹), Kosim¹), I Wayan Gunada1), I Nyoman Sri Putu Verawati ${ }^{1)}$ \\ 1)Program Studi Pendidikan Fisika, FPMIPA Universitas Mataram, Mataram, Indonesia \\ Corresponding author : Syahrial Ayub \\ E-mail : syahrial_ayub@unram.ac.id
}

Diterima 22 Maret 2020, Disetujui 28 April 2020

\begin{abstract}
ABSTRAK
Tujuan penelitian ini adalah mengetahui tingkat kesiapsiagaan siswa dan guru di sekolah dasar terhadap bencana alam. Sampel penelitiannya adalah 30 siswa kelas III, 35 siswa kelas V dan 15 orang guru SD Negeri 6 Mataram. Pengumpulan data dilakukan melalui penyebaran angket yang terdiri dari 5 aspek kebencanaan, yaitu (1) pengetahuan dan (2) tanda-tanda, dampak, (3) resiko dan upaya mengurangi, (4) kesiapsiagaan serta (5) prosedur dan alat pertolongan pertama pada korban. Tingkat kesiapsiagaan terhadap bencana alam bagi siswa di kategorikan cukup $(69,32 \%)$, dengan rincian sangat baik $(80,02 \%)$ aspek (1), baik $(78,00 \%)$ aspek (2), baik $(74,60 \%)$ aspek (3), kurang $(56,00 \%)$ aspek (4), dan kurang $(58,00 \%)$ aspek (5). Tingkat kesiapsiagaan terhadap bencana alam bagi guru di kategorikan cukup $(61,71 \%)$, dengan rincian kurang $(56,11 \%)$ aspek (1), kurang $(49,33 \%)$ aspek (2), baik (73,33\%) aspek (3), baik (79,05\%) aspek (4), dan kurang (53,33\%) aspek (5). Berdasarkan data dapat disimpulkan tingkat kesiapsiagaan terhadap bencana siswa dan guru di SD Negeri 6 Mataram dikategorikan kurang.
\end{abstract}

Kata kunci : analisis; kesiapsiagaan; bencana; siswa dan guru; sekolah dasar.

\begin{abstract}
The purpose of this study was to determine the level of student and teacher preparedness in primary schools against natural disasters. The research sample was 30 third grade students, 35 fifth grade students and 15 teacher for SD N 6 Mataram.Data collection is done through questionnaires consisting of 5 aspects of disaster, knowledge and signs, impacts, risks and efforts to reduce, preparedness and procedures and first aid tools for victims. The level of preparedness for natural disasters for students is categorized as sufficient $(69.32 \%)$, with very good details $(80.02 \%)$ aspects $(1)$, good $(78.00 \%)$ aspects (2), good (74.60\%) aspects (3), less (56.00\%) aspects (4), the less category $(58.00 \%)$ aspects (5). The level of preparedness for natural disasters for teachers is categorized as sufficient $(61.71 \%)$, with inadequate details $(56.11 \%)$ aspects $(1)$, less $(49.33 \%)$ aspects $(2)$, good $(73.33 \%)$ aspects (3), good (79.05\%) aspects (4), and the less category (53.33\%) aspects (5). Based on the data it can be concluded that the level of preparedness for student and teacher disasters in SD Negeri 6 Mataram is the less category.
\end{abstract}

Keywords : analysis; preparedness; disaster; student and teacher; elementary school.

\section{PENDAHULUAN}

Bencana gempa bumi dan tsunami di Aceh dan Sumatera Utara yang terjadi pada tahun 2004 tergolong bencana dahsyat bahkan membawa dampak ke wilayah yang lebih luas seperti Sri Lanka. Beberapa penelitian yang dilakukan setelah bencana, menyebutkan bahwa banyaknya jumlah korban disebabkan para korban tidak mempunyai pengetahuan tentang ancaman gempa dan tsunami. Gempa bumi yang disebabkan oleh pelepasan tekanan dari lempengan yang bergerak, semakin lama semakin membesar dan akhirnya mencapai pada keadaan dimana tekanan tersebut tidak dapat ditahan oleh pinggiran lempengan (Ella, 2008).

Gempa bumi yang terjadi di bawah laut mengakibatkan terjadinya gerakan kerak bumi ke atas dan ke bawah yang kemudian menyebabkan dasar laut naik dan turun secara tiba-tiba. Pergerakan naik dan turun dasar laut ini seterusnya menggerak-kan air laut, menciptakan pergerakan gelombang yang kuat dan ketika gelombang ini sampai di pantai atau daratan, kecepatannya melambat dan tumbuh menjadi tembok air yang tinggi (Ella, 2008). Dampak primer yang ditimbulkan dari bencana gempa bumi terdiri dari gonjangan tanah dan getaran tanah. Guncangan tanah dapat 
menyebabkan kerusakan dan kehancuran bangunan serta kemungkinan timbulnya tsunami yang merupakan bencana sekunder akibat gempa bumi yang berpusat di dasar laut (Psb-UGM, 2009). Lombok sebagai salah satu pulau di wilayah Indonesia yang sangat rentan terjadinya gempabumi. Baru baru ini di tahun 2018 antara bulan Juli sampai Agustus pulau Lombok diguncang 4 kali gempa bumi berkekuatan besar, yaitu 29 Juli 2018 kekuatan 6,4 SR, 5 Agustus 2018 kekuatan 7 SR, 9 Agustus 2018 kekuatan 6,2 SR dan 19 Agustus 2018 berkekuatan 7 SR ditambah dengan rentetan gempa susulan yang mencapai 2500 kali. Hal ini terdampak luar biasa pada masyarakat di pulau Lombok terutama di daerah pantai, pegunungan dan perkotaan. Ditandai dengan hancurnya bangunan dan infrastruktur di daerah yang terdampak dan yang sangat memilukan adalah terdapatnya korban ratusan korban jiwa pada rentetan gempa Lombok ini. Hasil observasi dan studi pendahuluan menunjukkan bahwa kesadaran masyarakat terhadap gempa bumi sangat kurang dan mitigasi gempa bumi juga sangat kurang. Gempa bumi merupakan bencana alam yang tidak dapat diprediksi kapan terjadinya sehingga bisa terjadi tiba-tiba seperti saat bekerja, tidur, bermain, dan bahkan juga saat belajar di sekolah. Anak-anak adalah kelompok yang paling rentan menjadi korban gempa bumi demikian juga guru dan perangkat sekolah lainnya. Maka dari itu mereka sangat perlu dibekali konsep gempa bumi secara umum konsep bencana. Ada beberapa jenis bencana lain yaitu: tsunami, tanah longsor, banjir, kekeringan, badai dan bencana gunung api. Guru sebagai ujung tombak di sekolah merupakan orang yang sangat menentukan bagi peserta didik untuk dapat memahami berbagai aspek yang dibutuhkan tentang kesiapsiagaan bencana. Kesiapsiagaan merupakan salah satu upaya yang dilakukan untuk mengantisipasi kemungkinan terjadi bencana untuk meng-hindari adanya korban jiwa, kerugian harta benda dan perubahan tata kehidupan masyarakat di kemudian hari (Sutton, 2006). Menurut (BNPB, 2012) kesiapsiagaan adalah serangkaian kegiatan yang dilakukan untuk mengantisipasi bencana melalui pengorganisasian serta melalui langkah yang tepat guna dan berdaya guna. Sedangkan (Nurmayani, 2018) mendefinisikan kesiapsiagaan mejadi lebih luas yaitu "meminimalisir akibat-akibat yang merugikan dari suatu bahaya lewat tindakan-tindakan pencegahan yang efektif, rehabilitasi dan pemulihan untuk memasti-kan pengaturan serta pengiriman bantuan dan pertolongan setelah terjadi bencana secara tepat waktu dan efektif". Upaya kesiapsiagaan yang dilakukan pada saat bencana mulai teridentifikasikan, antara lain; (a) pengaktifan pos-pos siaga bencana dengan segenap unsur pendukung, pelatihan siaga/simulasi/gladi/teknis bagi setiap sektor penanggulangan bencana (SAR, sosial, kesehatan, prasarana dan pekerjaan umum), (c) inventarisasi sumber daya pendukung kedaruratan, (d) penyiapan dukungan dan mobilisasi sumber daya/ logistik, (e) penyiapan sistem informasi dan komunikasi yang cepat dan terpadu untuk mendukung tugas kebencanaan, (f) penyiapan dan pemasangan instrumen sistem early warning, (g) penyusunan contingency plan, Olehkarena itu, pada penelitian ini digambarkan kesiapsiagaan guru dalam menghadapi bencana terutama di SD Negeri 6 Mataram. Ada 5 aspek besar yang digambarkan pada penelitian ini, yaitu: (1) pengetahuan dan tanda tanda akan terjadinya bencana, (2) dampak yang ditimbulkan bila terjadi bencana, (3) resiko dan mengurangi resiko bencana, (4) kesiapsiagaan menghadapi bencana, dan (5) prosedur dan alat pertolongan pertama pada korban. Tergambarnya kesiapsiagaan guru dalam menghadapi bencana akan menjadi dasar utama untuk menanamkan kesadaran bencana pada peserta didik. Kesiapsiagaan guru dan peserta didik akan mengurangi resiko bencana yang terjadi. Menurut (BNPB, 2012) risiko bencana adalah potensi kerugian yang ditimbulkan oleh bencana pada suatu wilayah dan kurun waktu tertentu, yang dapat berupa kematian, luka, sakit, jiwa terancam, hilangnya rasa aman, mengungsi, kerusakan atau kehilangan harta, dan gangguan kegiatan masyarakat. Oleh karena itu, pengurangan risiko bencana merupakan rencana terpadu yang bersifat lintas sektor dan lintas wilayah serta meliputi aspek sosial, ekonomi dan lingkungan. Dalam implementasi, kegiatan pengurangan risiko bencana nasional akan disesuaikan dengan rencana pengurangan risiko bencana pada tingkat regional dan internasional. Dalam hal ini masyarakat sebagai subjek dan objek sekaligus sasaran utama upaya pengurangan risiko bencana dengan berupaya mengadopsi serta memperhatikan kearifan lokal dan pengetahuan tradisional yang ada dan berkembang dalam masyarakat. Simulasi, sosialisasi dan pelatihan tentang penanggulangan bencana yang pernah dilakukan oleh pemerintah NTB maupun dari berbagai organisasi sepertinya tidak mempunyai dampak yang baik. Hal ini dikarenakan masih adanya korban jiwa akibat 
bencana. Atas dasar hal tersebut di atas, maka tujuan penelitian ini untuk mengkaji pengetahuan dan tanda tanda, dampak, resiko dan upaya mengurangi, kesiapsiagaan, prosedur dan alat pertolongan pertama pada korban bencana.

\section{METODE PENELITIAN}

Penelitian ini menggunakan metode kualitatif dan kuantitatif, dengan variabel penelitian yaitu kesiapsiagaan menghadapi bencana yang terdiri dari aspek pengetahuan dan tanda tanda akan terjadinya bencana, dampak yang ditimbulkan bila terjadi bencana, resiko dan mengurangi resiko bencana, kesiapsiagaan menghadapi bencana, dan prosedur dan alat pertolongan pertama pada korban. Data penelitian ini didapat dari hasil pemberian kuesioner. Sampel penelitian yaitu guru SD Negeri 6 Mataram. Selanjutnya, data kuantitatif yang didapat dari perhitungan kuesioner dideskripsikan berdasarkan data tambahan berupa pengamatan selama penelitian dan dikaitkan dengan penelitian terdahulu yang sesuai. Populasi dalam penelitian ini adalah seluruh guru SD Negeri 6 Mataram. Sampel penelitian ini adalah lima belas orang guru SD Negeri 6 Mataram yang diambil secara random (random sampling). Data didapat melalui kuisioner yang terdiri dari lima aspek kesiapsiagaan. dan serta divalidasi oleh ahli untuk bahasa dan penulisannya. Selain itu, data pendukung didapat dari dokumentasi, studi literatur, dan lainnya yang dibutuhkan dengan melibatkan guru dan pegawai di SD Negeri 6 Mataram. Penilaian dilakukan menggunakan skala Likert (Sugiyono, 2018) dengan memberikan nilai tertinggi 1 untuk jawaban setuju, nilai 0 untuk jawaban tidak setuju Untuk mendapatkan prosentase dari setiap aspek digunakan rumus berikut :

$$
\mathrm{Pn}=\frac{\text { skor aspek } \mathrm{N}}{\text { skor maksimum aspek } \mathrm{N}}
$$

dimana, $\mathrm{Pn}$ adalah prosentase aspek $\mathrm{N}$. Instrumen yang digunakan dalam penelitian terlebih dahulu divalidasi dan dilakukan uji coba terbatas, yang bertujuan untuk mengetahui validitas dan reliabilitas dari kuesioner untuk ke 5 aspek kesiapsiagaan. Validitas merupakan suatu ukuran yang menunjukkan tingkat kesahihan suatu tes
(Arikunto, 2006). Teknik analisa data untuk data kualitatif yang digunakan dalam penelitian ini sesuai dengan pernyataan (Moleong, 2007) bahwa proses analisa data kualitatif dimulai dengan menelaah seluruh data yang tersedia dari berbagai sumber, yaitu dari wawancara, pengamatan yang sudah dituliskan dalam catatan lapangan, dokumen pribadi, dokumen resmi, gambar, video dan sebagainya. Langkah berikutnya adalah mengadakan reduksi data atau memilih hal-hal pokok yang sesuai dengan fokus penelitian. Reduksi data merupakan suatu bentuk analisis yang menggolongkan, mengarahkan, mengorganisasikan dan membuang data yang tidak diperlukan. Oleh karena itu, reduksi dilakukan dengan jalan abstraksi yang merupakan usaha membuat rangkuman serta pernyataan yang tetap. Setelah data direduksi maka dipilih data yang diperlukan dan dikelompokkan berdasarkan informasi yang telah disusun. Apabila didapatkan data yang kurang maka dilakukan penyempurnaan data dengan cara mencari kembali baik melalui wawancara atau dokumen yang ada. Tahap terakhir dari analisa data adalah mengadakan pemeriksaan keabsahan data sebelum pemaparan dan analisa terhadap data untuk menarik kesimpulan dari hasil penelitian.

\section{HASIL DAN PEMBAHASAN \\ Kesiapsiagaan Siswa}

Berdasarkan kelima aspek kesiapsiagaan bencana pada siswa SD Negeri 6 Mataram nilai prosentase jawaban untuk semua siswa tergambar pada gambar $1 \mathrm{di}$ bawah ini:

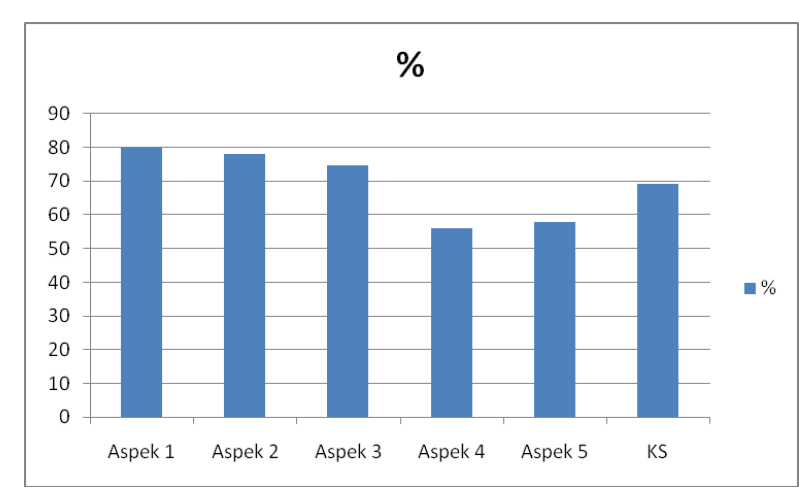

$$
\begin{gathered}
\text { Gambar } 1 \text { : Prosentase } 5 \text { aspek } \\
\text { kesiapsiagaan bencana pada Siswa SD } \\
\text { Negeri } 6 \text { Mataram }
\end{gathered}
$$

Secara rinci aspek 1 merupakan pengetahuan dan tanda-tanda akan terjadinya bencana tergambarkan $80,02 \%$, aspek 2 yaitu dampak yang ditimbulkan bila terjadi bencana $78,00 \%$, aspek 3 yaitu resiko dan upaya 
mengurangi resiko bencana $74,60 \%$, aspek 4 yaitu kesiapsiagaan siswa dalam menghadapi bencana $56,00 \%$, aspek 5 yaitu prosedur dan alat pertolongan pertama pada korban $58,00 \%$ sedangkan secara keseluruhan kesiapsiagaan guru dalam menghadapi bencana adalah $69,32 \%$. Angket ini mengungkapkan kesiapsiagaan dan pertolongan pertama pada korban bencana berada pada kategori kurang. Hal ini memberikan gambaran bahwa siswa sekolah dasar belum siap melakukan kegiatan mengantisipasi bencana melalui pengorganisasian dan langkah yang tepat guna dan berdaya guna serta melakukan pertolongan pertama pada korban bila terjadi bencana.

\section{Kesiapsiagaan Guru}

Berdasarkan kelima aspek kesiapsiagaan bencana pada guru SD Negeri 6 Mataram nilai persentase jawaban untuk semua guru tergambar pada gambar $2 \mathrm{di}$ bawah ini:

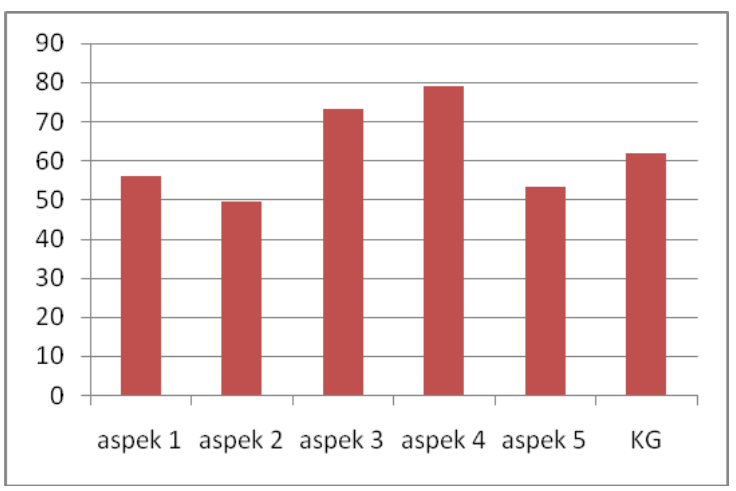

Gambar 2. Prosentase 5 aspek kesiapsiagaan bencana pada guru SD Negeri 6 Mataram

Secara rinci aspek 1 merupakan pengetahuan dan tanda-tanda akan terjadinya bencana tergambarkan $56,11 \%$, aspek 2 yaitu dampak yang ditimbulkan bila terjadi bencana $49,33 \%$, aspek 3 yaitu resiko dan upaya mengurangi resiko bencana $73,33 \%$, aspek 4 yaitu kesiapsiagaan guru dalam menghadapi bencana $79,05 \%$, aspek 5 yaitu prosedur dan alat pertolongan pertama pada korban $53,33 \%$ sedangkan secara keseluruhan kesiapsiagaan guru dalam menghadapi bencana adalah $61,71 \%$.

Berdasarkan hasil sebaran kuesioner ini, tergambar aspek kebencanaan yang masuk kategori kurang adalah tentang (1) pengetahuan dan tanda tanda akan terjadinya bencana, (2) dampak yang ditimbulkan bila terjadi bencana, dan (3) prosedur dan pertolongan pertama pada korban bencana. Kurikulum kebencanaan belum ada di sekolah, hal inilah yang menyebabkan aspek (1), (2) dan (3) berada pada kategori kurang karena pada aspek ini merupakan pengetahuan, sikap dan keterampilan yang harus dimiliki guru dalam aspek kebencanaan dan ini harus diajarkan, dilatihkan dan di sosialisasikan pada guru. Hal ini diperkuat oleh pernyataan Rattien bahwa ilmu pengetahuan dan teknologi sangat mempengaruhi kesiapsiagaan dalam menghadapi bencana. Oleh karena itu, peningkatan aspek pengetahuan sangat diperlukan karena akan berdampak pada aspek yang lain. Hal ini bertujuan untuk dapat menyelamatkan dan mengurangi banyak korban jiwa, dislokasi, dan kerugian ekonomi yang diakibatkan oleh bencana gempa bumi. Sedangkan dari aspek kesiapsiagaan dan upaya mengurangi resiko berada pada kategori baik. Hal ini sesuai dengan bidang mereka sebagai guru harus mempunyai kepekaan yang besar terhadap usaha usaha yang harus dilakukan pada peserta didik bila terjadi bencana saat mereka berada di sekolah, di samping itu guru juga harus mempunyai kepekaan dalam upaya mengurangi resiko bencana. Hal ini sudah dibuktikan secara ilmiah oleh guru di SD Negeri 6 Mataram. Selain itu, pengalaman dan latar belakang pendidikan mereka juga mendukung dalam menguasai pengetahuan tentang bencana. Hal ini didukung oleh pernyataan (Gunawan, 2008), bahwa kesiapsiagaan dalam menghadapai bencana alam didapat dari pengalaman. Oleh sebab itu, dengan pengetahuan yang baik dan mempunyai pengalaman, maka terbentuklah sikap yang baik dan tepat dalam menghadapi bencana. Secara keseluruhan, aspek kebencanaan pada guru SD Negeri 6 Mataram berada pada kategori cukup $(61,71 \%)$. Kesiapsiagaan masyarakat yang tepat dan efektif dalam menghadapi bencana dapat dilihat dari sejauh mana mereka dapat tanggap dalam merespon bencana, yang sesuai dengan pernyataan (Herdwinarti, 2010). Hal ini dapat diketahui dari hasil wawancara dan jawaban kuesioner tentang aspek kesiapsiagaan dalam menghadapi bencana. Selain itu, kesiapsiagaan dalam menghadapi bencana juga dapat mengurangi risiko yang 
ditimbulkan dari bencana tersebut (Sutton, 2006).

Semua guru yang dilibatkan dalam penelitian adalah mereka yang pernah mengalami bencana gempa bumi di Lombok tahun 2018, sehingga dapat diketahui kesiapsiagaan mereka dalam menghadapi bencana gempa bumi. Hal ini sama dengan pernyataan (Priyanto, A. 2006) yang menyatakan bahwa masyarakat yang belum memiliki pengalaman langsung dengan bencana seringkali mengabaikan kesiapan menghadapi bencana. Berdasarkan pengalaman inilah mereka menjadi lebih siap dalam menghadapi bencana gempa bumi. Analisa ini memberikan gambaran dan informasi kepada kita bahwa pembelajaran kebencanaan pada guru, peserta didik, pegawai dan kepala sekolah harus segera diterapkan pada kurikulum pendidikan di sekolah.

\section{Kesiapsiagaan Guru SD Negeri 6 Mataram dalam Menghadapi Bencana}

Aspek kesiapsiagaan guru dalam menghadapi bencana termasuk dalam kategori baik. Hasil ini dikarenakan sebagian besar mereka mengalami bencana gempa bumi yang terjadi pada bulan Juli sampai dengan Desember 2018 sehingga lebih mempunyai kesiapsiagaan yang tepat dalam mengahadapi bencana gempa bumi. Pengalaman mereka ini kemudian diceritakan kembali kepada saudara dan keturunannya sehingga mereka juga dapat mengetahui dan ikut merasakan pengalaman menghadapi bencana gempa bumi yang terjadi. (Gunawan, 2008) yang menyatakan bahwa pengalaman mengalami bencana dapat membentuk kesiapsiagaan yang tepat, dan pernyataan (Nasution, 2011) bahwa pendidikan dan pengalaman merupakan faktor yang dapat mempengaruhi pengetahuan.

Aspek ini berisi pertanyaan tentang apa yang dilakukan peserta didik sebelum, saat akan ada tanda-tanda akan terjadi bencana, saat menyelamatkan diri menuju daerah yang aman dan saat yang dilakukan sampai pada daerah yang aman. Pengetahuan, sikap dan keterampilan tentang ini harus terbentuk pada diri peserta didik sehingga timbul tingkat kesadaran terhadap bencana. Hal ini sesuai dengan pernyataan (Anderson and King. 2005) bahwa pengetahuan dan kesiapsiagaan dalam menghadapi bencana dibutuhkan dalam mitigasi komunitas terhadap bencana. Hal yang sama juga dinyatakan oleh (LIPI, 2006) bahwa pengetahuan dan sikap mengenai kesiapsiagaan menghadapi bencana adalah kemampuan yang harus dimiliki oleh setiap individu sebagai wujud dari kesiapsiagaan dalam menghadapi bencana. Perubahan tingkah laku peserta didik berkat adanya pengalaman yang diberikan melalui latihan untuk dapat menyelesaikan masalah yang dihadapi (Ismayawati, B. 2016)

\section{SIMPULAN DAN SARAN}

\section{Simpulan}

Secara keseluruhan dari 5 aspek kebencanaan dapat disimpulkan :

(1) Tingkat kesiapsiagaan siswa dan guru SD Negeri 6 terhadap bencana dikategorikan kurang.

(2) Tingkatan itu mencakup kesiapsiagaan dan pertolongan pertama pada korban bencana.

(3) Faktor kesiapsiagaan dan pertolongan pertama pada korban bencana perlu mendapat perhatian lebih lanjut khususnya bagi guru, siswa, kepala sekolah dan pegawai SD Negeri 6 Mataram dan sekolah sekolah lain yang akan menjadi imbas kegiatan penelitian ini.

\section{Saran}

Saran dalam penelitian ini untuk meningkatkan kesiapsiagaan masyarakat dalam menghadapi bencana adalah:

(1) Menerapkan pelatihan dan sosialisasi berkaitan dengan kesiapsiagaan dalam menghadapi bencana bagi semua sekolah yang rawan bencana terutama di daerah pesisir, pegunungan dan perkotaan.

(2) Melibatkan masyarakat untuk ikut serta dalam kegiatan yang berhubungan dengan kesiapsiagaan dalam menghadapi bencana seperti tsunami, gempa bumi, banjir, tanah longsor, gunung meletus, kekeringan, dan badai.

(3) Melakukan penelitian lebih lanjutan pada beberapa masyarakat sekolah bencana lainnya, sehingga bisa terpetakan tingkat kesiapsiagaan guru, siswa, kepala sekolah dan pegawai. 


\section{UCAPAN TERIMA KASIH}

Terima kasih kepada LPPM Universitas Mataram yang telah mendanai kegiatan penelitian ini dan Kepala Sekolah SD Negeri 6 Mataram yang telah memberikan kesempatan kepada tim untuk melakukan penelitian beserta guru dan siswa nya. Penelitian ini tidak akan berhasil dilaksanakan tanpa bantuan dari mereka. Semoga Allah SWT memberikan keberkahan pada mereka.

\section{DAFTAR RUJUKAN}

Anderson and King. (2015). Mitigation of The Impact of Tropical Cyclones in Northern Australia through Community Capacity Enhancement". 10(3), 367392.

Arikunto, S. (2006). Prosedur Penelitian Suatu Pendekatan Praktek. Jakarta: Rineka Cipta.

Badan Nasional Penanggulangan Bencana. (2012). Peraturan Kepala Banda Nasional Penanggulangan Bencana Nomor 1 Tahun 2012 tentang Pedoman Umum Desa/Kelurahan Tangguh Bencana. BNPB

Ella dan Usman. (2008). Mencerdasi Bencana. Jakarta: Grasindo.

Gunawan. (2008). Kondisi Sosial Masyarakat dalam Manajemen Bencana. Yogyakarta.

Herdwinarti, F., dan Sudaryono. (2013). Perbedaan Kesiapsiagaan Menghadapi Bencana Ditinjau dari Tingkat Self-Efficacy pada Anak Usia Sekolah Dasar di Daerah Dampak Bencana Gunung Kelud. Universitas Airlangga. Jurnal Psikologi Kepribadian dan Sosial, 2(1), 35-41.

Ismayawati, B. (2015). Pengaruh Model Pembelajaran Berbasis Masalah (PBM) dalam Setting Pembelajaran Kooperatif Tipe TGT dan GI terhadap Kemampuan Berpikir Kritis dan Hasil Belajar Kimia Peserta Didik SMA N 1 Aikmel. Jurnal Penelitian Pendidikan IPA, 2(1). 54-65.

Lembaga Ilmu Pengetahuan Indonesia (LIPI) UNESCO/ISDR. (2006). Kajian Kesiapsiagaan Masyarakat dalam Mengantisipasi Bencana Gempa Bumi dan Tsunami. Jakarta. Deputi IImu Pengetahuan Kebumian Lembaga IImu Pengetahuan Indonesia.

Moleong, J. (2007). Penelitian Kualitatif. Bandung. PT Rosdakarya

Nasution, S. (2011). Metode Research (Penelitian Ilmiah.). Jakarta: Bumi Aksara.

Nurmayani, L.,. (2018). Pengaruh Model Pembelajaran Inkuiri Terbimbing
Terhadap Hasil Belajar Peserta Didik. Jurnal Penelitian Pendidikan IPA, 4(2). 23-28

Priyanto, A. (2006). Promosi Kesehatan Pada Situasi Emergensi Edisi 2. Jakarta.

PSB-UGM. (2009). Reorientasi Pendidikan Kebencanaan dalam Rangka

Pengurangan Risiko Bencana.

Seminar Nasional. Reorientasi

Pendidikan Kebencanaan

Yogyakarta

Sugiyono. (2013). Metode Penelitian

Pendidikan

Pendekatan Kuantitatif dan Kualitatif. Bandung. ALFABETA.

Sutton, J., Tierney, K. (2006). Disaster Preparedness: Concepts, Guidance and Research. University of Colorado. Colorado 